[街 $\mathrm{EISEI}$ 生 $\mathrm{KAGAKU}^{\text {华 }}$

29 (6) $389-393(1983)$

\title{
カドミウムによる精巣障害の発症過程における脂質過酸化の関与について
}

佐二木順子，福島悦子，藤代良彦 千葉県衛生研究所

\section{Involvement of Lipid Peroxidation to the Early Stage of the Injury in Rat Testis Induced by Cadmium}

\author{
Junko SAJIKI, Etsuko Fukushima \\ and YOSHIHIKo FUJISHIRO \\ Chiba Prefectural Institute of Public Health \\ Nitona-cho, Chiba 280, Japan
}

(Received May 24, 1983)

To investigate when the changes of lipoperoxide contents in early stage of the inflammation are induced in the testis of rats after $\mathrm{CdCl}_{2}$ injection, we measured the lipoperoxide contents in plasma and tissues (liver, kidney and testis) at $1,3,5,10,15,24$ and $48 \mathrm{~h}$ after $\mathrm{CdCl}_{2}(5.0 \mathrm{mg} / \mathrm{kg})$ injection.

Lipoperoxide value in the testis increased significantly from $15 \mathrm{~h}$ after $\mathrm{CdCl}_{2}$ injection. Although no change of lipoperoxide value was observed in the liver through the experimental period, the value in the kidney increased significantly at 10 and $48 \mathrm{~h}$ after $\mathrm{CdCl}_{2}$ treatment.

Heme protein value which represents the degree of hemorrhage in the testis also increased from $15 \mathrm{~h}$ after $\mathrm{CdCl}_{2}$ injection. This suggests that hemorrhage in the testis has a good correlation with an increase in lipid peroxidation in situ.

The fact that significant increases in lipoperoxide values and in the degree of hemorrhage were observed from $15 \mathrm{~h}$ after $\mathrm{CdCl}_{2}$ injection, reveals the possibility that oxidative reactions occur in the testis of rats nearly $15 \mathrm{~h}$ after the treatment.

Assay of enzyme activities in serum was performed simultaneously. The activity of $\beta$-glucuronidase which is considered to be one of parameters showing the occurrence of an inflammation, increased significantly at an early time (from 1 to $5 \mathrm{~h}$ ) after $\mathrm{CdCl}_{2}$ treatment. This implies that some biochemical reactions occur in the testis before the time when the increase of lipoperoxide formation occurs.

In the liver where no fluctuation of lipoperoxide concentration was observed during the experimental period, the $\mathrm{Zn}$ contents increased as the time elapsed after $\mathrm{CdCl}_{2}$ administration. On the contrary, a significant reduction of the $\mathrm{Zn}$ content was observed in the testis in which a considerable increase in lipoperoxide concentration was noticed, at $3-5 \mathrm{~h}$ after $\mathrm{CdCl}_{2}$ administration. The inflammation of testis by $\mathrm{Cd}$ is supposed to be initiated at this time stage.

The difference of the $\mathrm{Zn}$ contents in these tissues may be considered to be one of factors which induce the difference among tissues in lipoperoxide concentration.

Keywords - cadmium ; inflammation; rat testis ; lipid peroxidation; serum enzyme; tissue metal

は じめに

Parizek ${ }^{1)}$ によりカドミウムによる精巣障害が 報告さ れて以来, 精巣障害についての多くの研究があるが, 障 害発現のメカニズムについては明らかにされていない。
Gabor $5^{2)}$ が脂質の 過酸化の 精樂障害への関与を報 告して以来，我々も塩化カドミウムをラットの皮下に投 与すると，24時間後には精巣に出血性の炎症が生じ，そ の際，精栄の過酸化脂質値は有意な增加を示すことを報 
告した. 3) また，この過酸化脂質の增加は，抗酸化剂で あるビタミン $\mathrm{E}$ の前投与により，ほぼ正常值まで抑兄ら れ, 炎症の程度も著しく軽隇された。これらの実験結果 から, 我々はカドミウムにより生成がえ進された過酸化 脂質が精巣に战ける炎症の発現に関与していることを示 唆した.4)

今回は, 脂質の過酸化といら現象が精巣の炎症の直接 の原因になっているかどらか知るため, カドミウム投与 後経時的に過酸化脂質値の測定を行ない，他の炎症のパ ラメーターとの関連について検討した。

\section{実 験 方 法}

1. 実験材料络ィスター系雄ラット（体重 $200 \mathrm{~g}$ 前後）35匹に塩化カドミウム $\left(\mathrm{CdCl}_{2}\right) 5.0 \mathrm{mg} / \mathrm{kg}$ を皮 下注射し，注射後，1，3，5，10，15，24，48 時間泟各 5 匹ずつ殺処分を行なった。エーテル麻酔の上心臟より 採血を行ない, 直ちに藏器 (肝臟, 腎藏, 精栄)をとり 出し, 臟器重量の测定を行なった。

2. 血清中の醏素測定心採血飞ょり得た血液を $2000 \times \boldsymbol{g}, 10$ 分間遠心し，血清を分離した。乳酸脱水素 酵素 (LDH) アルカリホスファターゼ (Al-P) の测定 は，オートアナライザー（ABBOTT-VP）を用い，醳

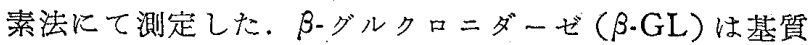
飞 $p$-ニトロエニルグルクロナイドを用い，生成され る遊離 $p$-ニトロフェノールを测定する方法5徒い，活 性值は，一特間あたりの 表した。

\section{3. 血漿中ならびに䁍器中の過酸化脂質の測定 血} 嶈中過酸化脂質の測定は，チォン゙ルビッール酸法(TBA 法 $)^{6 \supset}$ 飞より測定した。贜器中過酸化脂質は, Ohkawa らによるTBA 法てにもとづいて測定した。

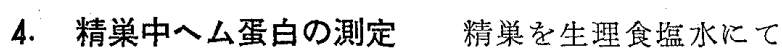
ホモジナイズした後， $2000 \times \boldsymbol{g} ， 5$ 分間遠心した。得ら れた上清について，二波長分光光度法8) $\left(\lambda_{2}=540 ， \lambda_{1}=\right.$ $560 \mathrm{~nm}$ ）にてへム蛋白量を測定した。二波長分光光度 計は日立 557 形を用いた。

5. 臓器中 Cd, Zn の測定 各臟器 $(500 \mathrm{mg}-1 \mathrm{~g})$ 飞硝酸 $(2 \mathrm{ml})$ を加光湿式分解したのち，フレーム原子 吸光法9)で $\mathrm{Cd}, \mathrm{Zn}$ 学测定した。原子吸光はPERKINELMER 305 を用いた。

血清中の醳素活性值 (A1-P 括上び LDH)，㵴器中過 酸化脂暨㯰については，誤差の分散が平均值飞比例して 特り，対数正規分布の特改を示していたので，測定值を 対数変換したのち，有意差検定（ $t$ 检定）を行なった. また，精栄中へム蛋白含量についても同㮐の理由により 適切な变換 $\left(x^{\prime}=\{\log (x+1)\}^{1 / 4}\right)$ を行なったのち $t$ 検
定を行なった。その他のパラメーターについては，その まま $t$ 検定により処理した。

結果

$\mathrm{CdCl}_{2}$ 投与後の精栄重量变化を Fig. 1 に示した. 投 与後10時間目から精巣重量は增加し $(p<0.05)$ 24時間 まで增加しつづけたが，48時間目のものでは減少した。

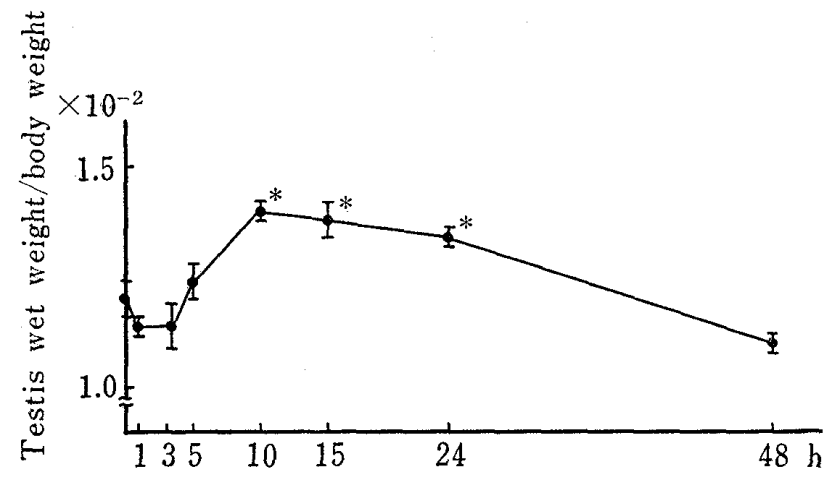

Fig. 1. Changes of Testicular Weight against to Body Weight with Time after $\mathrm{CdCl}_{2}$ Injection

Each Value represents the Mean $\pm \mathrm{SE}$ of 5 rats. Differences are tested according to $t$-test.
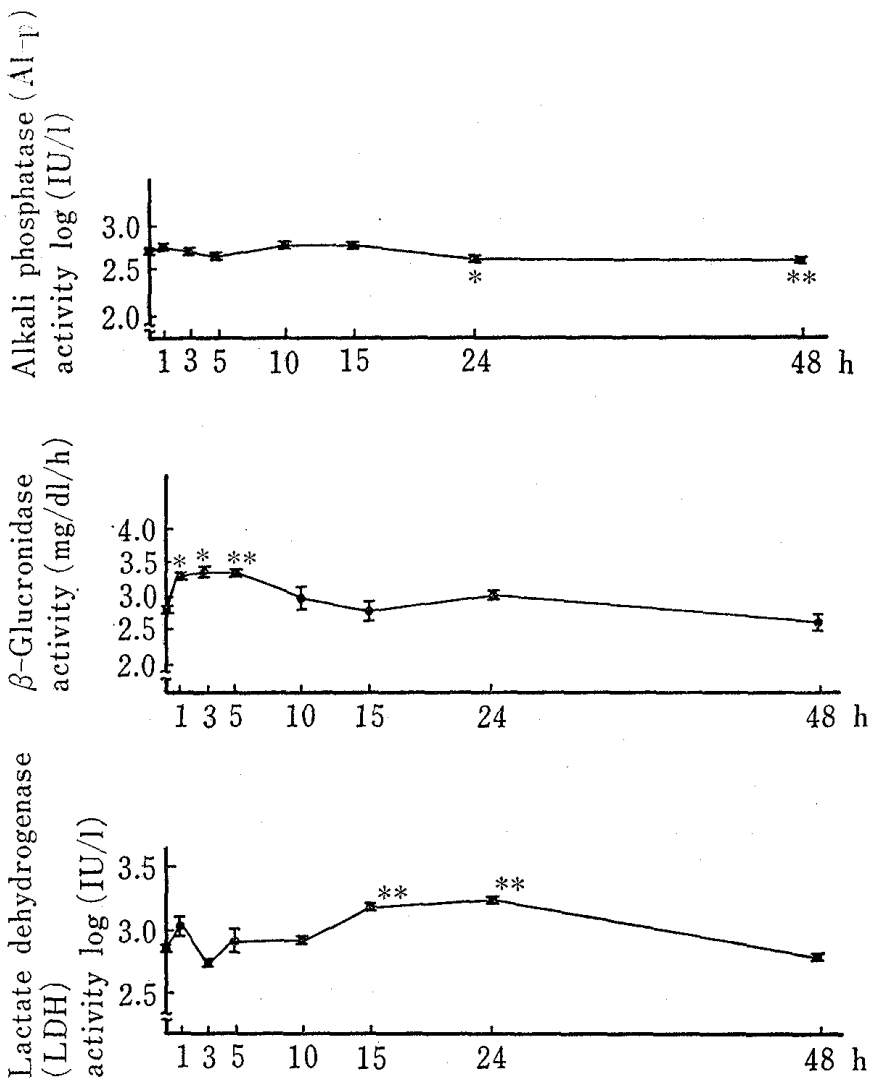

Fig. 2. Changes of Various Enzyme Activities in Serum with Time after $\mathrm{CdCl}_{2}$ Injection

Each Value represents the Mean $\pm \mathrm{SE}$ of 5 rats. Differences are tested according to $t$-test. 
TABLE I. Cadmium (Cd) and $Z$ inc $(\mathrm{Zn})$ Contents in Tissues with Time after $\mathrm{CdCl}_{2}$ Treatment

\begin{tabular}{|c|c|c|c|c|c|c|c|}
\hline \multicolumn{2}{|c|}{ Metals } & \multicolumn{3}{|c|}{$\left.\mathrm{Cd}^{a}\right)(\mu \mathrm{g} /$ wet wt. $)$} & \multicolumn{3}{|c|}{$\mathrm{Zn}^{a}(\mu \mathrm{g} /$ wet wt. $)$} \\
\hline $\mathrm{h}$ & Tissues & Liver & Kidney & Testis & Livsr & Kidney & Testis \\
\hline 0 & & N.D. & N. D.e & N. D. ${ }^{c \nu}$ & $39.48 \pm 1.22$ & $42.92 \pm 0.65$ & $22.80 \pm 0.43$ \\
\hline 1 & & $9.60 \pm 0.92$ & $1.43 \pm 0.10$ & $0.18 \pm 0.003$ & $31.45 \pm 0.44^{*(2)}$ & $26.85 \pm 0.90$ & $25.63 \pm 0.64^{* * b)}$ \\
\hline 3 & & $17.03 \pm 0.59$ & $1.65 \pm 0.03$ & $0.22 \pm 0.01$ & $38.82 \pm 1.08$ & $22.76 \pm 0.31$ & $20.73 \pm 0.31^{* b)}$ \\
\hline 5 & & $25.29 \pm 0.76$ & $2.98 \pm 0.17$ & $0.28 \pm 0.01$ & $43.36 \pm 0.90$ & $26.08 \pm 0.33$ & $17.70 \pm 1.21^{* b)}$ \\
\hline 10 & & $31.53 \pm 1.36$ & $3.53 \pm 0.13$ & $0.31 \pm 0.01$ & $49.40 \pm 0.51^{* * b)}$ & $24.98 \pm 0.27$ & $20.93 \pm 0.26$ \\
\hline 15 & & $37.56 \pm 2.03$ & $4.70 \pm 0.41$ & $0.33 \pm 0.03$ & $52.26 \pm 0.91^{* * b)}$ & $23.70 \pm 0.36$ & $21.45 \pm 0.63$ \\
\hline 24 & & $40.81 \pm 0.67$ & $5.92 \pm 0.32$ & $0.33 \pm 0.004$ & $63.12 \pm 0.77^{* *(3)}$ & $23.62 \pm 0.35$ & $24.08 \pm 0.53$ \\
\hline 48 & & $44.03 \pm 0.54$ & $14.97 \pm 0.74$ & $0.25 \pm 0.01$ & $67.58 \pm 1.37^{* * b)}$ & $25.10 \pm 0.39$ & $21.50 \pm 0.44$ \\
\hline
\end{tabular}

a) Mean $\pm \mathrm{SE}$ b) Differences are tested according to $t$-test of 5 rats. $\left.{ }^{* *} P<0.01,{ }^{*} P<0.05 \quad c\right) \quad N$. D., not detected.

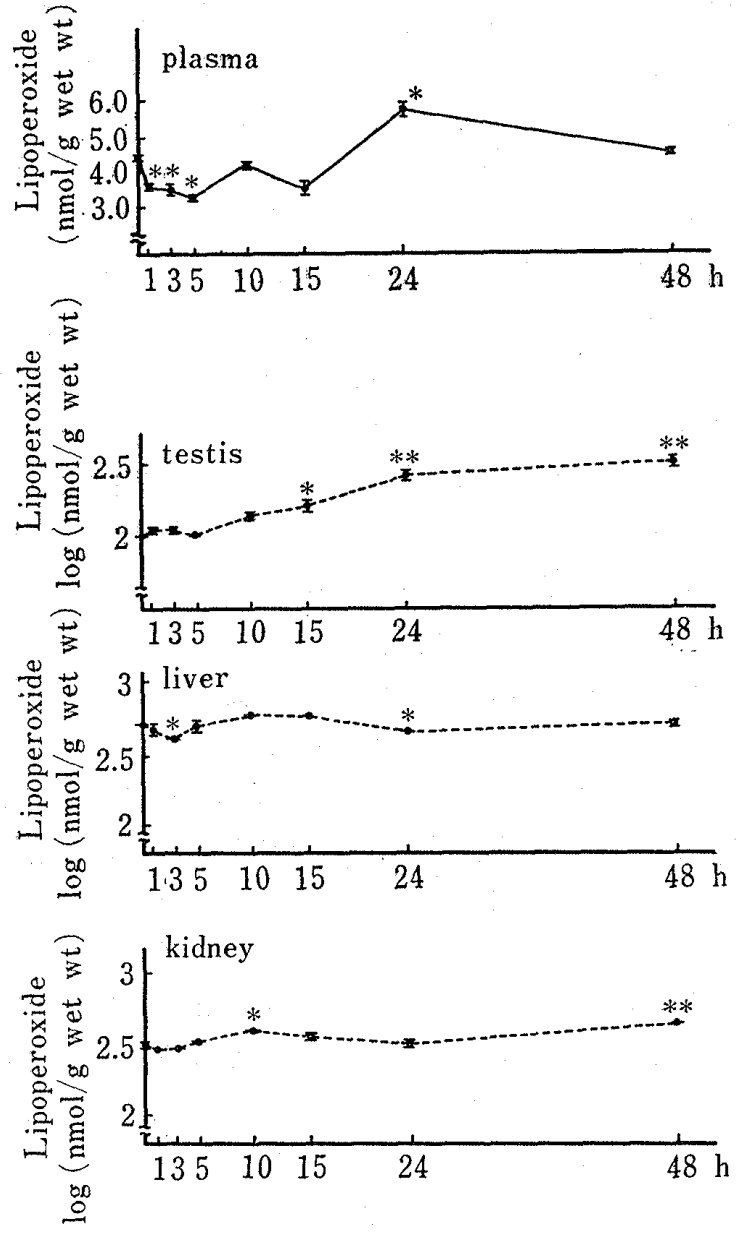

Fig. 3. Changes of Lipoperoxide Values in the Plasma and Tissues Measured by TBA Method

Each Value represents the Mean $\pm \mathrm{SE}$ of 5 rats. Differences are tested according to $t$-test.

血清中の Al-P, LDH， $\beta$-GL の時間経過による値の 変動は Fig. 2 に示したと和りであった，AI-P そつい ては，投与後24時間目から値の低下 $(p<0.05)$ が観察 され，48時間目にはさらに低下した $(p<0.01) . \mathrm{LDH}$

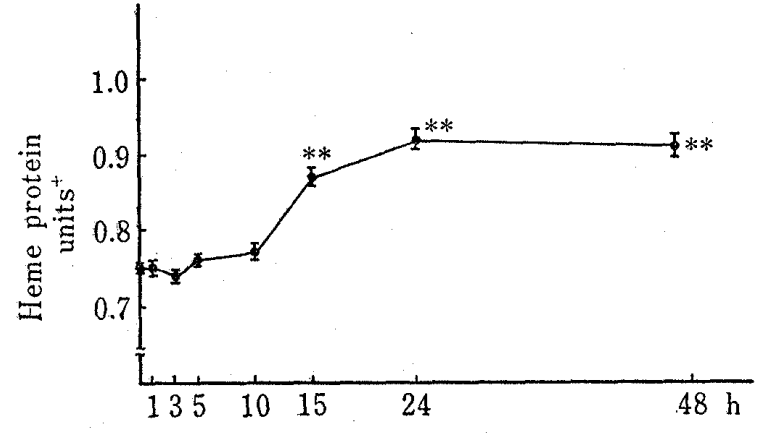

Fig. 4. Changes of Heme Protein Values Expressed as Hemoglobin in the Testis

Each Value represents the Mean $\pm \mathrm{SE}$ of 5 rats. Differences are tested according to $t$-test. +Units are described in "Methods" in detail.

については，15，24時間目に有意な值の增加が認められ た $(p<0.01) . \beta-G L$ は, 投与後 1 時間目に有意な值 の増加 $(p<0.05)$ が認められ，5時間目まで増加した $(p<0.01)$ が，その後は正常值にもどった.

血獎中の過酸化脂質值は, 投与後初期飞減少し, 増加 が認められたのは投与後24時間目のみ $(p<0.05)$ であ った (Fig. 3). 臟器中の過酸化脂質の時間経過にとも なら変動は，Fig. 3 に示したと物りであった，肝臓で は，実験期間中値の変動ば認められなかった。腎臓で は，投与後10時間目と48時間目に，それぞれ $5 ， 1 \%$ 不 我準で値の増加が認められた。精栄では，投与後15時間 目以降值の有意な增加が認められた。

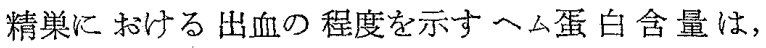
$\mathrm{CdCl}_{2}$ 投与後 15時間目に值加急速に增加し $(p<0.01)$, その後，24時間目まで徐々に增加した（Fig. 4).

臓器中 $\mathrm{Cd}, \mathrm{Zn}$ の含量の時間経過にともなら変動は, Table I に示したと捛である。投与後48時間目まで $\mathrm{Cd}$ の蓄積量は, 肝蔵が最も多かった。なお，肝蔵，腎 臓ともに Cdの蓄積量は，時間とともに增加したが，精 
巣では 15-24時間目がピークで，その後減少した。 Zn 含量については，肝缄で $\mathrm{CdCl}_{2}$ 投与後 1 時間目に一時 的に低下したが，その後徐々に堌加し，10時間以降の $\mathrm{Zn}$ 含量はコントロール ( 0 時間) 値に比べ有意に大き かった。精巣では肝臓と全く逆で，投与後 1 時間目に一 時的に増加し，3ー5時間目には低下したが，その後正 常にもどった．筒臓の $\mathrm{Zn}$ 含量には全く変化が見られな か⿰た。

\section{考察}

カドミウムをラットやマウスに投与すると, 精栄内血 管の透過性が著しく㠵進し，精栄に出血性の炎症をひき 扣こすことが明らかである．今回，出血程度を示す指標 と考えられるへム蛋白含量を湘定したところ， $\mathrm{CdCl}_{2}$ 投与後 15 時間目に精栄中の值は有意に 増加した.この 時間は Kar $5^{10)}$ がカドミウム投与ラットの精栄中に病 理学的見地から，血管障害ならびに出血を認めた時間 (12 時間前後) と注湾等しい，また， $\mathrm{CdCl}_{2}$ 投与後 15 時間目には過酸化脂質も精栄で有意に增加しており

(Fig. 2)，出血と脂質の過酸化とは深い関連があるも のと思われる。な和，細胞損傷のパラメーターの一つと 考えられている $\mathrm{LDH}$ が $\mathrm{CdCl}_{2}$ 投与後 15 時間目に血清 中で有意に増加したことは，この時期に組織障害が充進 していることを裏付けるものと考えられる．血清中の $\beta-\mathrm{GL}$ 活性值は， $\mathrm{CdCl}_{2}$ 投与後 1 時間目といら早い時期 に高まった(Fig. 2)． $\beta$-GL は炎症のパラメーターと して重要なライソゾーム酵素である，この酵素活性值が 投与後, 極めて早期に血清中で増加した事実は, 精巣で 出血, 脂質の過酸化の充進が観察される以前に炎症と関 連の深い何らかの生体反応が生じている可能性を示唆す るものと考觉られる．血清中で変動が認められたこれら の酵素については, 今後, 組織中の活性值との関連につ いて，さらに検討する必要がある。

Setchell ら ${ }^{11)}$ は，我々が用いた量とほほ等しい $\mathrm{CdCl}_{2}$ をラットに投与し, 投与後 $3-4$ 時間目にアイソトープ ラベルのアルブミンが精巣の血管外に漏出したことか ら，カドミウム投与後かなり早期に血管の透過性が圥進 していることを認めた。この事実は，血管の透過性のえ 進が脂質の過酸化反応に先行することを示しており，こ のことはとりるなおさず，過酸化脂質がカドミウムの精 巣炎症の直接の原因ではなく，炎症の発症過程で生ずる 反応生成物である可能性を示すものと考えられる.

最近, Shibata ら ${ }^{12)}$ は, $\mathrm{CdCl}_{2}(3.07 \mathrm{mg} / \mathrm{kg})$ を腹腔 内に投与し，炎症を生じたラット精巣中の脂質組成につ いて検討した。 それによると $\mathrm{CdCl}_{2}$ 投与後 6 時間以降 リン脂質含量は低下し，一方，アラキドン酸 (20:4),
ドュサペンタェン酸（22:5）等の 高度不飽和 脂肪酸の 遊離が認められた。これら遊離した不飽和脂肪酸は，エ ステル型のものやトリグリセリドに比べ過酸化速度汭速 いことが報告されている.13) また，アラキドン酸の遊離 の亢進が認められた事実は，酵素的脂質過酸化反応系で あるプロスタグランディン代謝を立進させている可能 性 ${ }^{14)}$ を示して括り， Shibata らの報告した脂肪酸の 遊離が精栄内での脂質の過酸化を助長している可能性は 大きい。

カドミウムの蓄積量の最も大きな肝蔵では，脂質の過 酸化の克進が全く認められなかったのに反し，腎臓でも 精策と同椂増加が認められた（投与後 10 時間目; $p<$ $0.05 ， 48$ 時間目 ; $p<0.01)$. このようなカドミウム障 害の臓器間に生ずる善の 原因について Gunn ら 器間での血管の形態学的な差を考觉た。しかしながら， カドミウムの毒性を調節している因子と考兄られている メタロチオネインの各藏器に和ける関与の違いも障害の 蔵器間差を生みだす一因と考学られる。 Wong ら カドミウムのひき括こす精巣障害の程度はラットの週路 により異なるが，この障害程度の差には必ずしも×タ口 チオネインが関与しているとは限らないことを述べてい る. 今後, カドミウムの存在形態と脂質の過酸化との関 連について検討することは，障害の藏器間差の原因を究 明する上で有意義と考えられる。

肝臓では，毒性発現抑制機構としてとりこまれた $\mathrm{Cd}^{++}$が $\mathrm{Zn}$ ・チオネインの $\mathrm{Zn}^{++}$と置換する事実が明ら かにされている.17） 今回，実験期間中過酸化脂質の増加 が認められなかった肝臓に叔いてはZ Znの著しい增加が 観察され, 一方, 過酸化脂質の増加が認められた精㲘, 腎臓で $\mathrm{Zn}$ 含量が低かった事実は，Zn と脂質の過酸化 作用との関連性を示唆するものである. Zn がライソン゙ 一ム膜の脂質の過酸化を抑えるという報告もあり,18) 今 後, カドミウム中毒時に精栄で観察される脂質の過酸化 作用に和けるZnの役割について，さらに検討を加える 必要が市らう。

\section{ま と め}

カドミウム投与により，ラット精巣で生ずる出血性炎 症の発症過程における過酸化脂質の变動を調べた。

$\mathrm{CdCl}_{2}(5.0 \mathrm{mg} / \mathrm{kg})$ 皮下注射後 15 時間目に精栄中の 過酸化脂質値は有意な増加を示し, 以降増加した。 た, 精巣内の出血程度を示すへム蛋白含量も投与後15時 間以降増加し，脂質の過酸化之出血との関連が示唆され た。䀒臓では笑験期間中過酸化脂質值に変動はみられな かったが，腎蔵では投与後10，48時間目に有意に增加し た。 
炎症のパラメーターである $\beta$ グルクロニダーゼは， 血清中の測定項目中最も早く（投与後 $1-5$ 時間）活性 值が上昇した。

以上の結果より, $\mathrm{CdCl}_{2}$ 投与後 15 時間前後に精巣内 で酸化反応が兄進し，重篤な炎症に進展するものと考光 られる、な拈，脂質の過酸化が生ずる以前に何らかの炎
症に関連した反応が生体内で生じていることが示唆され た。

また，実験期間中過酸化脂質值に変動が認められなか った肝藏では Zn 含量が時間とともに増加したが,一 方, 過酸化脂質値が 増加した 精巣では $\mathrm{CdCl}_{2}$ 投与後 3 一5時間目に Zn 含量は低下した。

\section{参考文 献}

1) J. Parizek, Z. Zabor, Nature (London), 177, 1036 (1956); J. Parizek, J. Endocr., 15, 56 (1957).

2) S. Gabor, Z. Anca, E. Bordas, Rev. Roum. Biochim., 15, 113 (1978).

3) J. Sajiki, Y. Fukuda, E. Fukushima, J. Appl. Biochem., 3, 467 (1981).

4) J. Sajiki, Y. Fukuda, E. Fukushima, A. Hirai, Y. Tamura, A. Kumagai, J. Appl. Biochem., 4, 339 (1982).

5) K. Kato, K. Yoshida, H. Tsukamoto, M. Nobunaga, T. Masuya, T. Sawada, Chem. Pharm. Bull., 8, 239 (1960).

6) K. Yagi, Biochem. Med, 15, 212 (1976).

7) H. Ohkawa, N. Ohishi, K. Yagi, Anal. Biochem., 95, 351 (1979).

8) B. Chance, Science, 120, 767 (1954).

9) W. Slavin, S. Sprague, F. Rieders, V. Cordova, Atomic Absorption News-letter, 4, 7 (1964).

10) A.B. Kar, R.P. Das, Acta Biol. Med. Germ., 5, 153 (1960).

11) B.P. Setchell, G. M.H. Waites, J. Endocr., 47, 81 (1970).

12) T. Shibata, Y. Yoshida, K. Waku, 衛生化学, 29, p. 46 (1983).

13）浅川具美，野村幸弘，松下雪郎，油化学，24，88(1975).

14) 早石 修, 山本尚三, 医学のあゆみ, 81, 247 (1972).

15) S. A. Gunn, T.C. Gould, W.A. D. Anderson, Amer. J. Pathol., 42, 685 (1963).

16) K.L. Wong, C.D. Klaasen, Toxicol. Appl. Pharmacol, 55, 456 (1980).

17) K. Tanaka, S. Onosaka, M. Doi, K. Okahara, 衛生化学, 23, 229 (1977).

18) M. Chvapil, J.N. Ryan, C.F. Zukoski, Proc. Soc. Exp. Biol. Med., 141, 150 (1972). 